\title{
Livelihood Economic Activities Causing Deforestation in Northern Ghana: Evidence of Sissala West District
}

\author{
Clifford James Fagariba ${ }^{*}$, Shaoxian Song2, Serge K. G. Soule ${ }^{3}$ \\ ${ }^{1}$ School of Environment and Natural Resource Engineering, Wuhan University of Technology, Wuhan, China \\ ${ }^{2}$ Hubei Key Laboratory of Mineral Resources Processing and Environment, Wuhan University of Technology, Wuhan, China \\ ${ }^{3}$ School of Environment and Natural Resource Engineering, Wuhan University of Technology, Wuhan, China \\ Email: *cfagariba@yahoo.com
}

How to cite this paper: Fagariba, C.J. Song, S. and Soule, S.K.G. (2018) Livelihood Economic Activities Causing Deforestation in Northern Ghana: Evidence of Sissala West District. Open Journal of Ecology, 8, 57-74.

https://doi.org/10.4236/oje.2018.81005

Received: November 9, 2017

Accepted: January 28, 2018

Published: January 31, 2018

Copyright $(0) 2018$ by authors and Scientific Research Publishing Inc. This work is licensed under the Creative Commons Attribution International License (CC BY 4.0).

http://creativecommons.org/licenses/by/4.0/

\begin{abstract}
Policymakers and international organizations are making the conscious effort to address climate change through afforestation and sustainable ecosystem management. Economic activities including agriculture, mining, and infrastructure improvement to meet basic human needs continuously degrade the natural and forest resources. The rate of deforestation in Ghana is alarming due to over-reliance on forest resources by forest-dependent communities. Perceived causes of deforestation differ from individuals and groups perspective. This depends on factors including environmental knowledge, education level, market demand and socio-economic activities. Simple random sampling and key informant interview with the aid of semi-structured questionnaire was used to elicit information from the indigenes of Sissala West District to determine their perceptions of causes of deforestation. The study indicated that poverty, high illiteracy, population growth and lack of alternative source of livelihood were the indirect causes which trigger livelihood economic activities such as farming, charcoal burning, wood logging and hunting leading to degradation of the ecosystem. It was also realized that majority of the indigenes are uneducated and this contributes to their unawareness of rate of deforestation. Recommendations suggested to address challenges were enforcement of bye-laws and stringent government environmental policies to deter people from degrading the forest. Education, agroforestry, afforestation, and provision of alternative livelihood were also good interventions suggested.
\end{abstract}

\section{Keywords}

Deforestation, Livelihood Activities, Underlying Causes, Forest Communities 


\section{Introduction}

Policymakers and international organizations are making the conscious effort to address climate change through afforestation and sustainable ecosystem management. Economic activities including agriculture, mining, and infrastructure improvement to meet basic human needs continuously degrade the natural and forest resources. Forests hold a significant quantity of global carbon with $294 \mathrm{Gt}$ of carbon stored in forest cover, $42 \mathrm{Gt}$ in dead wood and $324 \mathrm{Gt}$ in soils and litter [1]. Studies have shown that overall carbon content of the forests which was estimated at $658 \mathrm{Gt}$ as of 2009 is more than the quantity of carbon in the entire atmosphere [2]. This shows that life on earth will be virtually unsustainable without the existence of forests. International organizations including UN Framework Convention on Climate Change (UNFCCC), the UN Convention on Biological Diversity (CBD) and the UN Convention to Combat Desertification (UNCCD) all acknowledge the immeasurable contribution of forests to addressing issues related to climate change, global warming, poverty and diseases [3]. Experts estimate that global deforestation contributed about $20 \%$ of annual greenhouse gas emissions in the 1990s-2005 [4].

In developing countries, factors including poor education, poor income, high poverty level and economic hardships compel forest fringe communities to degrade the forest resources for food, income, and shelter [5]. Unsustainable forest resource exploitation, especially in developing countries for economic growth, has contributed to global warming, climate change, health issues, poor yield and extinction of certain plant and animals species [6]. Studies have shown that deforestation continuously triggers drought and dry spell issues in most part of Africa hence threatening food security and poverty alleviation on the continent [7]. Other research suggested that Africa vast tropical rainforest and fertile land is a great potential for sustainable agriculture and poverty alleviation if policies efficiently address deforestation challenges [8]. About $90 \%$ of African countries dwell directly or indirectly on agriculture and forest products for employment and food security [9]. This implies that if pragmatic solutions are not implemented to address forest degradation, there would be undesirable consequences on the continent. Related findings indicate that Africa governments' poor implementation of forest conservation policies has affected food security to the extent that countries within Sudan and the Sahel Region are likely to face extreme hunger and poverty by 2035 [10]. Formation of regional forest conservation networking system to shares ideas and research findings would help in controlling environmental degradation activities affecting the full functioning of the ecosystem.

Ghana being one of the African countries with Agriculture as the economic backbone needs to tackle environmental degradation constraints rigorously by bringing on board all stakeholders who invariably contribute to sustainable environmental management. Ghana land area comprises 32.05\% forest and $67.05 \%$ savanna of which $20 \%$ about $15,871.70 \mathrm{~km}$ sq is reserved as permanent forest while $391 \mathrm{~km}$ sq is off-reserves [11]. Permanent forest estate in the savanna zone 
covers about $8806 \mathrm{~km}$ sq or $5.63 \%$ of the total area while unreserved savanna woodland constitutes about 73,467 $\mathrm{km}$ sq or $48.29 \%$ [12]. Studies have revealed that Ghana is said to have lost over $80 \%$ of its forest cover in a century [13]. An original forest cover of 8.2 million hectares has been reduced drastically to about 1.7 million hectares with average destruction rate of 75,000 hectares per annum [14]. The rate of degradation points to a gloomy future for the country's forest. Every part of the country has got its fair share of the impact of the environmental destruction through the loss of scenery, fauna and flora, wildlife habitation, ecosystem and water resources.

Deforestation occurs in many ways. Most of the clearing is done for agricultural purposes and also the provision of fuelwood for domestic use. Studies indicated that farmers generally prefer technologies that save labor and capital rather than land to expand agriculture [15]. This means that the type of technology farmers readily to adopt is the one most likely to increase forest clearing. Deforestation by a peasant farmer is often done to raise crops for self-sustenance and is driven by the basic human need for food. Peasant farmers who chop down small area (typically a few acres) and burn the tree trunks to prepare their land for farming perceive modern agriculture which involves the use of heavy machines such as tractors and bulldozers to clear large areas to promote deforestation. Commercial logging which involves cutting trees for sale as timber or pulp is also one of the main causes of deforestation in Ghana. The perceptions of causes of deforestation are very complex and can be tackled from different angles depending on how one perceives the causes to be.

There is established empirical evidence that Ghana forest sector is dwindling as a result of poor sensitization of farmers, forest-fringe communities, and mining companies [16]. Similar research indicates that deforestation experienced in Ghana highly affects forest fringe communities especially those in the savanna areas of Northern Ghana [17]. Agriculture in Ghana is predominantly small scale with most of the farms less than 2 hectares due to a high cost of inputs and inadequate government support. As a result of climate change effect on yield, most farmers tend to rely on the forest resources for income and food supplement. Northern Ghana is noted for producing staple grains such as maize, millet, guinea corn and rice due to good climatic conditions for such crops. However, in recent times, high deforestation rate have created unfavorable climatic conditions for good yield. This has compelled most of the farmers to adapt by either migrating to the South to look for the nonexistent job during the dry season or change planting period from early April to late June to avoid drought, dry spell or any unforeseen threat.

There are many constraints contributing to forest communities' inability to effectively adopt prudent strategies to reduce economic activities which leads to deforestation. A better understanding of how these constraints influence forest communities preparedness of protecting the forest would enable researchers to strategically come out with reliable measures that could enhance forest conservation and sustainable rural livelihood activities. Forest communities choices of 
adapting to conservation strategies depend on many considerations they perceived as best decision to improve their livelihood. The effectiveness of forest community's adaptation strategy mainly depends on biophysical and socioeconomic factors such as farming experience, farm labor, weather extremes, income, household size, extension services, input cost, and age.

With regards to the above elaboration on the impact of deforestation in Ghana, the research is to assess factors influencing community forest conservation, the study also aimed at determining practices suitable for addressing constraints of forest conservation. The study would also attempt suitable interventions that could help address deforestation issues.

\section{Conceptual Framework}

Forest communities cannot leave without relying on forest resources for survival. In areas where sections of the community forest are the reserve for conservation purpose so as to continue protecting endangered plant and animal species, illegal invasion at odd hours for personal benefits undermine community sense of protection. Forest guards on many occasions have come under attack in dealing with poachers and chainsaw operators whose illegal activities endanger forest management. Research has established that forest issues can be addressed effectively if concern organization, stakeholders, and government agencies cooperate and work within a framework that seek to address issues holistically from all angles of forest community [18]. The conceptual framework of the study as shown in Figure 1 is based on the concept that, livelihood activities of forest communities create unsustainable forest management but the fringe communities cannot also do without. In this context, livelihood activities such as agriculture, mining, wood logging and hunting directly lead to employment, food production, income, economic growth and other social benefits. The adverse effects of livelihood activities have trickledown effects which end up causing unsustainable forest management. Climate Change, environmental degradation and global warming which is already experienced in the forest and nonforest communities as a result of the high demand of natural resources for human survival impact greatly on sustainable forest management [19]. The immediate resulted effect of unsustainable forest management could lead to poverty, hunger, extinction of wildlife and biodiversity, erosion and floods. This could have serious repercussions on communities near forest zones. Most forest communities mostly rely on the forest for food, meat, fruits, shelter and other products like beekeeping and mushroom production. If the forest is not sustained and all valuable products from the forest get depleted, fringe communities will find other alternative livelihoods due to resource appraisal for survival but the harm caused to the environment would take decades to be replaced. The root causes of unsustainable forest management could stem from the above-mentioned factors but the actual perceived causes could vary from a different perspective depending on factors that compel forest communities to involve in socioeconomic activities which degrade the forest. 


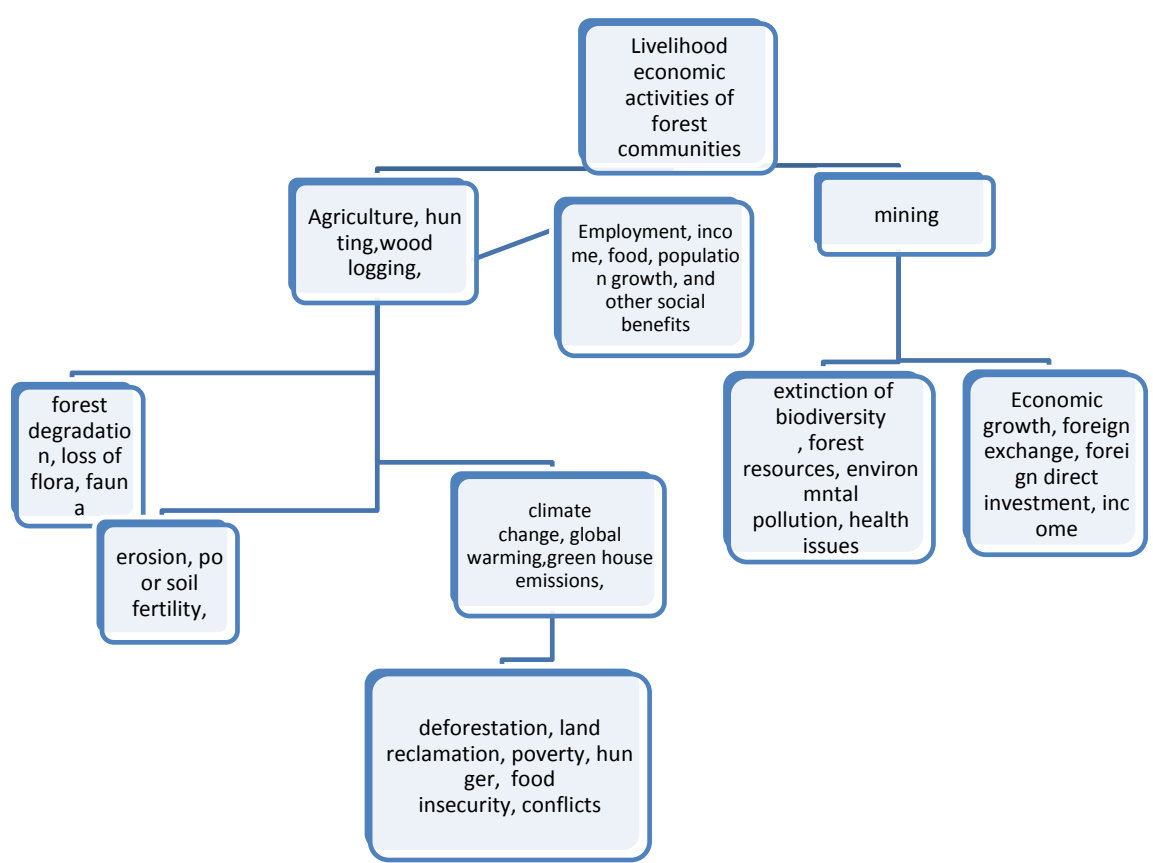

Figure 1. Conceptual framework of the study.

\section{Methodology}

\subsection{Study Area}

The total population of Sissala West District from recent Ghana Statistical updated 2015 report stood at 56,528 representing $8.1 \%$ of the region's total population. Males constitute 48.7 percent and females represent 51.3 percent. The population density is averagely 10 person square kilometers. The total land area of the district is about $41,289 \mathrm{~km}^{2}$ which is approximately $25 \%$ of the total land area of Upper West Region. The labor force of the district is estimated as 47,648 populations which are made up of 23,592 males and 24,056 females. The population of the labor force is between 15 to 64 years which is about the $49 \%$ of the entire population. This implies they have a good labor force. The vegetation cover of the district is Guinea Savanna which has been greatly transformed by climate and human economic activities such farming, wood logging, charcoal burns and poor husbandry practices. The district share border with Burkina Faso which serve as the entry point of Fulani nomads with large livestock during the dry season to search for greener pasture and water.

The district has low lying topography and some few streams dotted around the district. This has encouraged Government and NGOs to construct dams for irrigation and domestic use. However, the influx of Fulani Herds with a large number of cattle in the dry season coupled with deforestation along the dams banks end up drying some of these dams. The district as shown in Figure 2 has some forest reserves and some portion of Gbelle game reserve extend to the district at the eastern corridor of the Gbelle Community. As a result of rampant bushfire and falling down trees for charcoal, shelter, and fuelwood, the forest and the Gbelle game reserve have suffered some form of degradation. Introduction of 


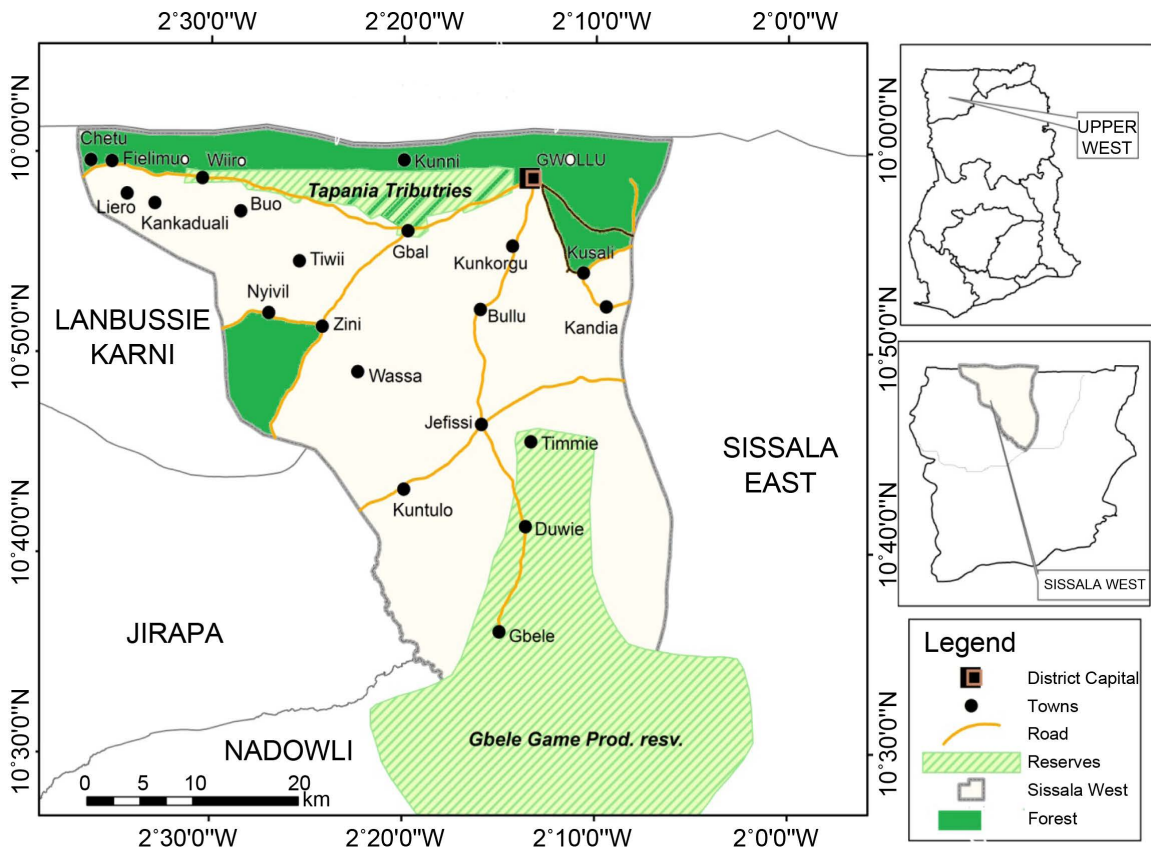

Figure 2. Map of Sissala west district source: Sissala west district assembly.

tractors and government subsidies for farm inputs has resulted in rapid farm expansion. This has also lead to the clearing of virgin forest for crop production. High Charcoal demand in the southern part of the country and neighboring Burkina Faso have to lead to most indigenes to engage in charcoal burns as employment. Economic trees such as shea, baobab, and dawadawa are those mostly used for charcoal production. The District Assembly and Forestry Commission have organized series of workshop to educate the locals about effects of charcoal burning and wood logging on the environment but this has not yielded good result.

\subsection{Design of the Study}

The study design used is purposive simple random sampling survey. This was adopted as a primary data collection format because of its systematic nature of data collection and simple way of data illustration for the clear representation of the research findings. Concern individuals, groups, and organizations that advocate for environmental protection were contacted for secondary data and relevant information.

Respondents who engage in charcoal business, farming, hunting, wood logging were contacted for information with the aid of a simple structured questionnaire. Key informant interview was organized for opinion leaders, assembly members and officials from Environmental protection Agency (EPA), Forestry Commission, Ministry of Food and Agriculture and the District Assembly Environmental officers. Five field officers were trained and supervised to aid in data collection due to the dispersed nature of settlements in the district. The data collection was time bound so their assistance helped to meet the deadline for questionnaire collection. The period for collecting the data lasted for 4 months 
(15/02/2016-21/06/2016).

A total of 330 respondents were interviewed. Additionally, 50 key informants and opinion leaders were contacted to express their view about the rate of deforestation in the district. In total 380 respondents and key informants were contacted for their opinion and necessary information.

\subsection{Model of the Research}

\subsubsection{Multiple Logistic Regression Models}

Logistic (logic) regression analysis is a widely used data analysis similar to the linear regression analysis except that with the logistic regression analysis the outcome is dichotomous (e.g. yes/no, low/high or true/false). Logic regression is used for determining the odds of an outcome of an event. It was used to determine factors having the possibility of influencing forest-dependent communities in degradation activities. Logical regression was able to determine the likelihood of breast cancer sustainability among some groups of women [20]. This implies that the logic regression model is able to predict the likelihood of the occurrence of an event. The outcome in logistic regression analysis is often coded as 0 or 1 , where 1 implies that the outcome of a finding is true and 0 indicates that the outcome of the finding is false. If $P$ in the equation is the probability that an outcome is 1 , the logic regression model can be express as:

$$
P=\operatorname{Prob}\left(Y_{i}=1\right)=\frac{1}{1+\mathrm{e}^{-\left(\beta+\beta_{1} X_{1 i}+\cdots+\beta_{k} X_{k i}\right)}}=\frac{\mathrm{e}^{\beta+\beta_{1} X_{1 i}+\cdots+\beta_{k} X_{k i}}}{1+\mathrm{e}^{-\beta+\beta_{1} X_{1 i}+\cdots+\beta_{k} X_{k i}}}
$$

Similarly

$$
P_{i}=\operatorname{Prob}\left(Y_{i}=0\right)=1-\operatorname{Prob}\left(Y_{i}=1\right)=\frac{1}{1+\mathrm{e}^{\beta+\beta_{1} X_{1 i}+\cdots+\beta_{k} X_{k i}}}
$$

Divide Equation (1) by 2

$$
\frac{\operatorname{Prob}\left(Y_{i}=1\right)}{\operatorname{Prob}\left(Y_{i}=0\right)}=\frac{P_{i}}{1-P_{i}}=\mathrm{e}^{\left(\beta+\beta_{1} X_{1 i}+\cdots+\beta_{k} X_{k i}\right)}
$$

where $P_{i}$ is the probability that $Y$ takes the value 1 and then $\left(1-P_{i}\right)$ is the probability that $Y$ is 0 and e the exponential constant.

$P$ is the expected probability that an outcome has the potential of being true or false. $X_{1 p}, X_{2 p}, X_{3 i}$ up to $X$ are independent variables which predict $P$ outcome; $\beta_{1}, \beta_{2}$ up to $\beta_{k}$ are regression coefficients of the independent variables. To predict the odd outcome of an event with known characteristic, substitute applicable values into the independent variables and take the log of the expected out come of the odds express as: $\frac{P_{i}}{1-P_{i}}=\mathrm{e}^{\left(\beta+\beta_{1} X_{1 i}+\cdots+\beta_{k} X_{k i}\right)}$

From the model equation, $P_{i}$ represents the probability of conserving the forest and $\left(1-P_{i}\right)$ represents the probability of non-adaptation.

The questionnaire used to elicit information from respondents and focus groups (FGDs) is attached as Appendix. The collected information was analyzed with SPSS, Logic regression model and WAI. 


\section{Results and Discussions}

\subsection{Factors Influencing Environmental Degradation}

Environmental degradation is mostly triggered by socio-cultural issues, economic policies, and technological challenges. Research findings indicated that biophysical, economic and social factors contribute immensely in determining forest degradation challenges [21]. The study as indicated in Table 1 establish that poor farm yield with 1.025 coefficients has the highest tendency of influencing forest communities who are mainly farmers to clear virgin lands for cropping in anticipation of obtaining a good yield. In the course of the survey, it came to light that most of the farmlands are dried and bare which indicates that the soil fertility in these areas is poor. This implied that farmers with poor soil fertility would abandon the infertile land and clear new field for cropping. Related studies indicate that high cost of farm inputs as a result of inadequate government subsidies and climate change impact on agriculture compels forest-dependent communities to clear forest land for cropping [22]. This suggests that farmers in forest areas would not hesitate to clear new areas for crop production in case there is a drastic reduction in yield as a result of poor soil fertility and unfavorable climatic conditions.

The study also indicated that forest-dependent income with the coefficient of 0.838 has a high probability of influencing fringe forest communities to degrade the forest for food, income, and other forest resources. Further inquiry revealed that forest communities with disposable income could easily engage labor, as well as use new technology including use of fertilizers, improved seeds and modern implements to avert impact of climate change on their farms. Education with the coefficient of 0.76 suggested that farmers with education have the high tendency of understanding consequences of environmental degradation on

Table 1. Determinants of perceived causes of deforestation $(\mathrm{N}=330)$.

\begin{tabular}{cccc}
\hline Variables & Coefficient & Standard error & P value \\
\hline Constant & 1.10 & 0.35 & 0.01 \\
Age & -0.36 & 0.72 & 0.53 \\
Education & $0.76^{*}$ & 0.83 & 0.34 \\
Forest guard services & $0.61^{*}$ & 0.07 & 0.00 \\
Gender & -0.30 & 0.60 & 0.74 \\
Forest-dependent income & $0.83^{*}$ & 0.05 & 0.00 \\
Household size & 0.20 & 0.04 & 0.00 \\
Access to weather information & $0.43^{*}$ & 0.16 & 0.09 \\
Alternative livelihood & $0.71^{*}$ & 0.11 & 0.00 \\
Cost of inputs & $0.52^{*}$ & 0.10 & 0.00 \\
High temperature and low rainfall & $0.46^{*}$ & 0.10 & 0.00 \\
Poor farm yield & $1.00^{*}$ & 0.13 & 0.00
\end{tabular}


agriculture and livelihood than farmers who have no any form of formal education. This implies that education enhances farmers knowledge and skills to predict the likelihood of deforestation impact on their farms so as to use appropriate countermeasures to prevent crop failure. Farmers with formal education have the enthusiasm of looking out for effective strategies or technologies to militate against unfavorable climatic condition in other to continue conserving the ecosystem resources [23]. Alternative livelihood with 0.714 coefficients was perceived as a factor with high possibility of influencing forest communities to degrade the ecosystem. Discussion with some community members suggested lack of alternative income generating source and food aside farming, force farmers to engage in biodegradable activities such as wood logging, charcoal production and indiscriminate hunting to earn a living. This suggests that alternative source of income generation activities including beekeeping, livestock rearing, and trading could support forest-dependent activities so as to reduce pressure on forest resources. Forest guard services $(0.616)$ were perceived as a factor capable of influencing forest communities to be conscious of the forest when engaging in their daily economic activities. Forest officers build forest-dependent communities capacity and equip them with skills that can help them to generate income without relying on the forest resources [24]. The study revealed that cost of input (0.526) also have the tendency of influencing reliance on the forest for cropping. The high cost of inputs such as fertilizers, weedicides, pesticides and tractor services could affect farmers' with infertile soil. On the other hand, low cost of inputs has a high tendency of compelling farmers to improve their soil fertility as well as yield. The research indicated that high temperature and low rainfall in the study area creating drought and dry spell force farmers to clear virgin forest area for cropping since they cannot afford high input cost. The logit analyses also indicated that access to weather information (0.438) was perceived as a factor with the significant possibility of influencing forest communities to take prompt action against climate change. Access to weather information according to researchers enable farmers to plan ahead of the farming season to avoid weather extremes such as flood, high temperature, drought and dry spell [25]. Discussions with the forest communities suggested that regular access to weather information reduce farmers susceptibility to climate change impact. Age and Gender with negative coefficient were perceived as factors with no tendency of influencing deforestation. Further inquiry showed that the indigenes perceive age as an inefficient factor in determining the level of degradation since both the youth and old engage in the same environmental degradation activities especially charcoal processing, farming and wood logging. This is contrary to other research findings which established that energetic youth have the tendency to engage in activities which causes huge destruction to the environment than older ones [26]. Gender was also not considered as an issue owing to the fact that most of the family comprising of husband, wives, and children engage in farming or charcoal processing together. Household size was perceived as a sensitive factor capable of influencing deforestation because the larger the household, the larger 
the family labor size for a bigger farm or other degradable activities. On the other hand, the smaller the household sizes the smaller the family labor hence the smaller the degradable activities. This implies, whereas bigger household tends to have more labor more environmental degradation is possible and vis versa.

\subsection{Livelihood Economic Activities}

More often than not, livelihood activities' having a direct impact on land and forest leads to environmental degradation. Human effort to tap forest resources for life necessities ends up destroying the natural ecosystem influencing forest carbon stock [27]. Research findings showed that forest contributes about $22 \%$ income of rural settings while agriculture (crops and livestock combined) and off-farm activities respectively contribute $37 \%$ and $38 \%$ income of rural settings [28]. This implies that the more forest land is used for agriculture and other forms of economic livelihood activities the less forest income becomes and hence those who solely depend on the forest for their livelihood will be at a disadvantage. Issues of global warming, climate change, erratic rainfall, air pollution and water pollution are due to unsustainable use of natural and forest resources [29].

Livelihood economic activities of the indigenes as illustrated in Figure 3 were basically traditional occupation they inherited from their ancestors. White color jobs in the district are government establishment with the majority of the workers been strangers from different parts of the country. The survey showed that out of 330 respondents interviewed 116 representing 35.2\% engage in farming while 77 respondents representing $23.3 \%$ were charcoal producers. Furthermore, hunting and wood logging represents 40 and 71 respondents respectively. The survey showed that $7.9 \%$ were traders who trade in both local and foreign commodities. The analyses showed that farming and charcoal production was the main source of livelihood in the district. This implies that though hunting and wood logging degrade the forest, farming and charcoal production is depleting the forest at an alarming rate.

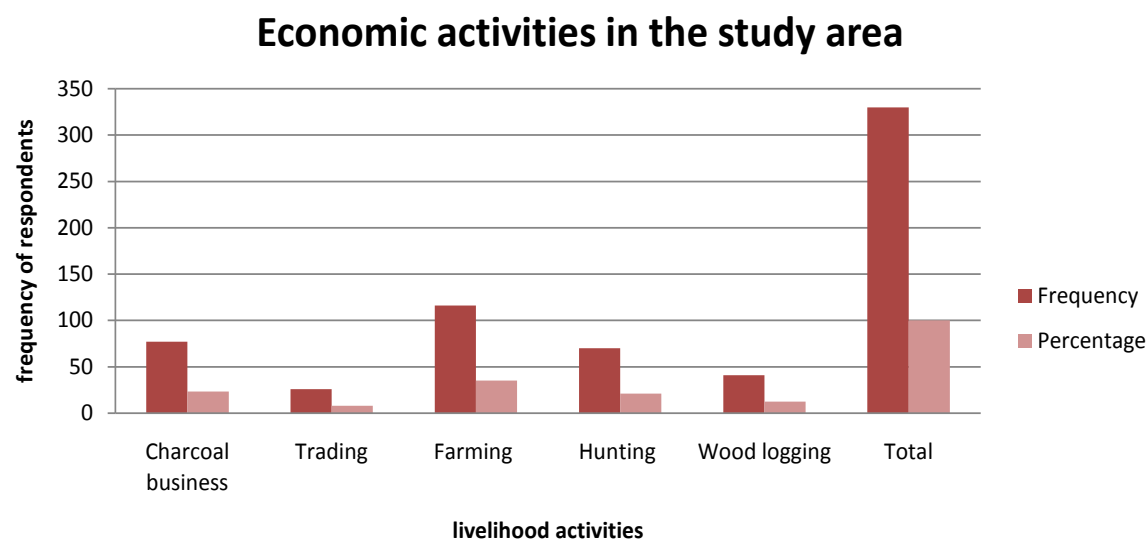

Figure 3. Livelihood economic activity (Source: Field Survey 2016). 


\subsection{Awareness of Deforestation}

Awareness of deforestation helps to put measures in place to address environmental degradation issues. Most people are not aware that problems associated with global warming, climate change, poor soil fertility, and drought are consequences of degradation caused by human activities. The study as indicated in Figure 4 established that 190 respondents out of 330 respondents sampled were aware of deforestation in the district. Meanwhile, 109 respondents were unaware of deforestation. This implies that the indigenes were aware their livelihoods activities adversely affect the environment but have no other source of alternative livelihood that could help them generate income for their living. Though most of the forest fringe communities are aware of deforestation they are not proactive in environmental management. Other studies revealed that forest-dependent vulnerability to poverty increases biodegradable activities in other to be more resilience [30]. This implies that should forest communities adapt to conditions in other to mitigate deforestation, they could start degrading forest if subsequently becomes vulnerable to poverty. According to the forestry commission officers, most of the indigenes do not take part in afforestation program that is occasionally organized to revamp the forest cover in the district.

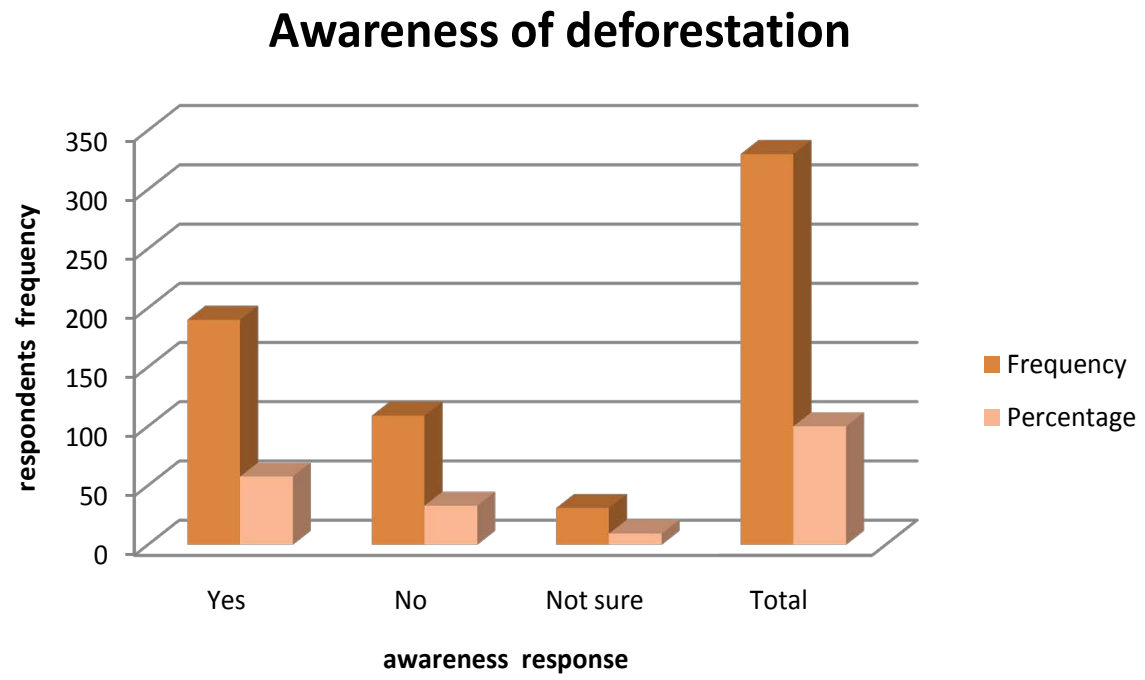

Figure 4. Awareness of deforestation (Source: Field Survey 2016).

\subsection{Direct Causes of Deforestation}

Causes of deforestation vary from individuals' perspective due to environmental issues pertaining to once environment. As people perceive lack of another source of alternative livelihood such as trading, small scales enterprises and industries in forest fringe community leads to over-dependence of forest resources for survival, others think poor government policies, lack of education, lack of community involvement and weak institutional capacities are the main underlying causes of deforestation or environmental degradation [31].

Studies have shown that community groups' involvement in protecting forest 


\section{Direct causes of deforestation}

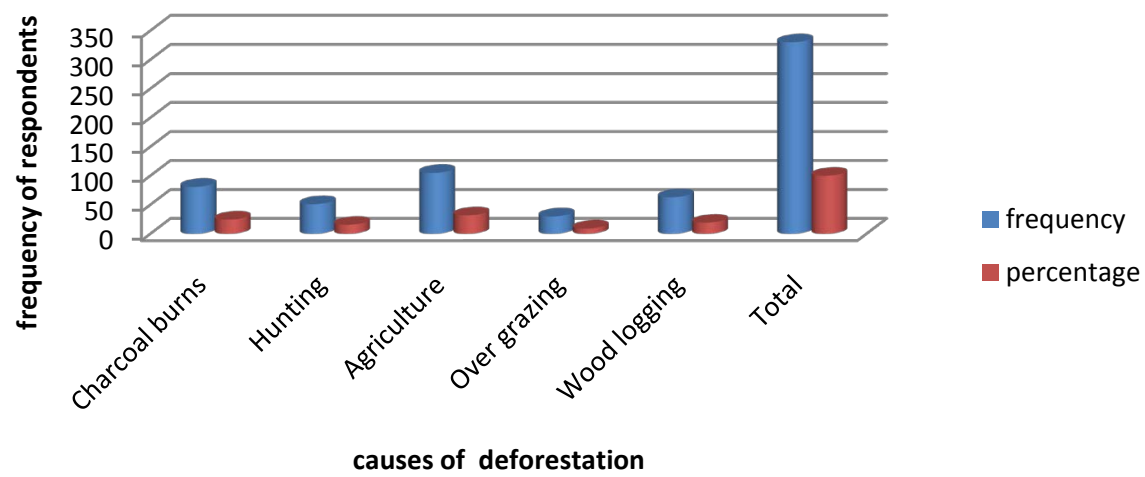

Figure 5. Direct causes of deforestation (Source: Field Survey 2016).

enhances sustainable forest management as decisions regarding forest protection would be an all-inclusive decision [32]. The study conducted as shown in Figure 5 indicated that agriculture and charcoal burns representing 31.8\% and 24.5\% respectively were perceived as the main causes of deforestation in the district. Agriculture and charcoal production is the main economic activity which serves as a source of income, employment, and food for the majority of the indigenes. Farm expansion with the aid of tractors leads to clearing large virgin lands including economic trees such as mahogany, rosewood, shea and dawadawa trees. As a result of annual farm expansion due to increase in population, large areas are deforested for crop production. The Ministry of Agriculture and Forestry Commission have held workshops for the indigenes on the need to practiced agroforestry so as to save the environment while ensuring sustainable crop production but this has not yielded any results. Wood logging representing 19.1\% was also seen as the threat to deforestation because the indigenes claim high demand for rosewood which is common in the district has compelled most of the youth to engage in illegal wood logging. Also, the demand for wood locally for infrastructure encourages chainsaw operators to cut down trees in the forest reserve areas. Overgrazing was considered the least cause of deforestation because this mostly happens during the dry season when there is an influx of Fulani herds with their cattle from Burkina Faso which shares the border with the district. They come to look for fresh pasture, fodder, and water for their cattle but consequently, large forest, farmland and protected areas are eventually destroyed.

\subsection{Indirect Causes of Deforestation}

There are several factors that indirectly trigger deforestation. Livelihood economic activities that are perceived to have an impact on the environment, as well as the forest, includes farming, overgrazing, wood logging, hunting, wildfire outbreaks and charcoal burning. If forest community is not proactive in protecting the forest at the expense of their livelihood activities, forest resources 
would be depleted and basic forest functions such as food, shelter and ecosystem protection cannot be realized. Research indicated that conflicts mostly occur when inadequacies of forest resources to support community needs increase the tendency of the elite and selected few to use the resources for their personal benefits [33]. There are lots of underlying factors that compelled people to engage in these activities and until those pertinent issues are addressed perceived causes of deforestation would continue to linger in the minds of people. The research indicates that indirect factors that serve as the root cause of deforestation include population growth, illiteracy rate, poverty, poor government policies and lack of alternative source of livelihood. Figure 6 illustrates the various responses from the respondents with regards to indirect causes of deforestation. The study showed that $32.4 \%$ of the respondents were of the opinion that population growth creates an issue of farm expansion, increased shelters, land fragmentation, land tenure issues and destruction of ecosystems to ensure human habitat survival. The high illiteracy rate among rural dwellers and forest fringe communities mostly dwelling on the forest and natural environment for survival lack knowledge on sustainable natural resource utilization.

The research indicated that $12.4 \%$ of respondents were of the view that illiteracy leads to misuse of available forest land for farming, wood logging, charcoal burning and any activity that would bring immediate benefit while compromising future consequences like climate change, global warming, drought and poor soil fertility. Meanwhile, lack of alternative livelihood representing $26.7 \%$ was seen by most of the respondents as the most serious factor that compels forest communities to engage in livelihood activities that causes deforestation. The district is not well developed so no investors want to risk venturing there. Therefore local people have taken upon themselves to use the land and the forest resources readily available to their advantage though some are aware of the rate of degradation. It was also realized that poor government policies representing $20.3 \%$ were also seen as an indirect factor contributing to deforestation. Poor enforcement of national forest policy creates poor community forest protection as well as the high tendency of poor forest resource management. Poverty was also seen as the least factor that triggers deforestation. The survey showed that

\section{indirect causes of deforestaion}

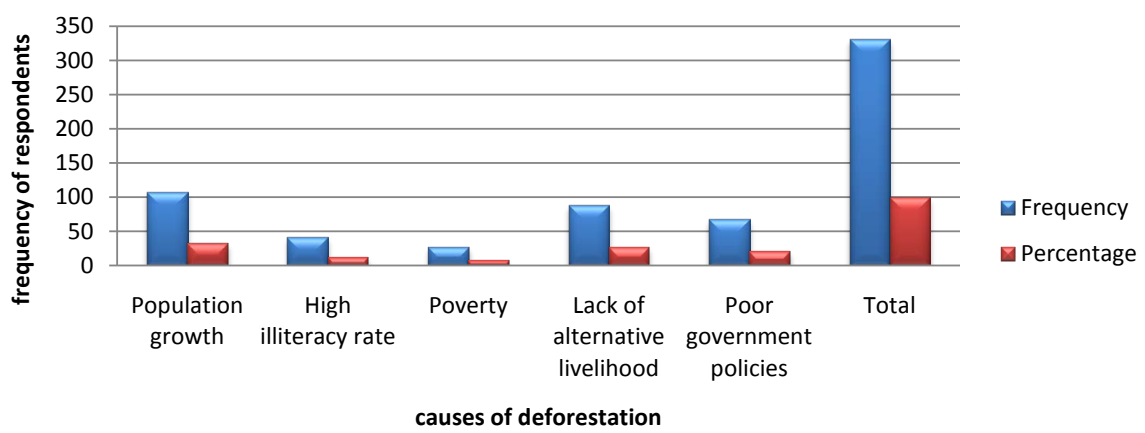

Figure 6. Indirect causes of deforestation (Source: Field Survey 2016). 
only $6.4 \%$ respondents attribute deforestation to poverty. This implies that among the factors that trigger deforestation activities, poverty was not considered to be much of a problem in the district though some of the indigenes who leave in abject poverty rely on the forest resources for food, shelter, and income which also cause deforestation to some extent.

\section{Conclusions}

The research findings revealed that most of the economic activities of the indigenes to some extent cause deforestation but some are more serious than others. Farming, wood logging and charcoal production were perceived as the main livelihood activities that have an immense impact on forest and ecosystem. It was realized that farm expansion as a result of population growth leads to land fragmentation and clearing virgin lands for crop production. High demand for charcoal in the district and other parts of the country encourages charcoal producers to expand their activities hence worsening deforestation rate in the district. It was also realized that high and ready market for wood log promotes the activities of chainsaw operators which end up degrading the forest.

Moreover, the high illiteracy rate among the indigenes does not promote environmental consciousness and these prevent them from adapting to strategies that would ensure sustainable forest resource utilization. Furthermore, the forest and wildlife policy framework do not involve most of the forest communities as stakeholders due to the poor education level of the indigenes hence creating security and management issues. This implies, forest fringe communities may not make the conscious effort to help in forest conservation when neglected. In addition, as the district experiences high birth rate due to polygamous marriage, population growth has led to the conversion of virgin forest into farming, charcoal production and other livelihood activities which subsequently degrade the forest. The rapid increase in population could increase economic activities of forest communities which subsequently degrade the forest situation where the forest is the only source of livelihood. The research findings indicated that lack of education, population growth and lack of alternative source of livelihood were perceived as indirect causes of deforestation while farming, charcoal production, and wood logging were perceived as direct causes of deforestation. The inference drawn from the research revealed that perceived indirect causes of deforestation trigger the direct causes of deforestation.

\section{Recommendations}

Forestry has become a critical part of the international biodiversity conservation agenda. Governments and international organizations have already agreed on the significance of REDD+, and have pledged financial support to initiate pilot activities. However, the long-term sustainability of REDD+ and forestry conservation will depend on important factors, including effective forest governance, forest community capacity building, and integration of climate change adapta- 
tion strategies into forest conservation policies.

Incorporating views and decisions of local people in government environmental policies to formulate good policies can address challenges of forest communities. This would encourage community participation in an environmental protection as well as forest management. Rigorous enforcement of environmental bye-laws at both national and community level to apprehend and punish those who engage in activities such as illegal wood logging and charcoal production would save as deterrent. Government interventions through the provision of alternative livelihoods such as dry season gardening, beekeeping and other skill training that could empower the local people to gain self-employment as well as income. Organisations and government agencies should embark on the massive campaign against deforestation. Agroforestry should be encouraged to protect the forest from been further degraded. Also, afforestation projects should be geared towards promoting agroforestry. The government should support farmers with suitable tree seedlings for agroforestry.

\section{References}

[1] FAO (2010) Global Forest Resources Assessment 2010. Main Report, FAO Forestry Paper 163. FAO, Rome.

[2] FAO (2011) State of the World's Forests 2011. http://www.fao.org/docrep/013/i2000e/i2000e00.htm

[3] Kurz, W.A. (2010) An Ecosystem Context for Global Gross Forest Cover Loss Estimates. Proceedings of the National Academy of Sciences of the United States of America, 107, 9025-9026. https://doi.org/10.1073/pnas.1004508107

[4] Gupta, J. (2012) Glocal Forest, and REDD+ Governance: Win-Win or Lose-Lose? Current Opinion in Environmental Sustainability, 4, 620-627. https://doi.org/10.1016/j.cosust.2012.09.014

[5] Shackleton, S., Paumgarten, F., Kassa, H., Husselman, M. and Zida, M. (2011) Opportunities for Enhancing Poor Women's Economic Empowerment in the Value Chains of Three African Non-Timber Forest Products (NTFPs). International Forestry Review, 13, 136-151. https://doi.org/10.1505/146554811797406642

[6] Maroto, C., Segura, M., Ginestar, C., Uriol, J. and Segura, B. (2013) Sustainable Forest Management in a Mediterranean Region: Social Preferences. Forest Systems, 22, 546-558. https://doi.org/10.5424/fs/2013223-04135

[7] Aicher, C. (2014) Discourse Practices in Environmental Governance: Social and Ecological Safeguards of REDD. Biodiversity and Conservation, 23, 3543-3560. https://doi.org/10.1007/s10531-014-0812-5

[8] De Brucker, K., Macharis, C. and Verbeke, A. (2013) Multi-Criteria Analysis and the Resolution of Sustainable Development Dilemmas: A Stakeholder Management Approach. European Journal of Operational Research, 224, 122-131. https://doi.org/10.1016/j.ejor.2012.02.021

[9] Nielsen, J.O. and Reenberg, A. (2010) Cultural Barriers to Climate Change Adaptation: A Case Study from Northern Burkina Faso. Global Environmental Change, 20, 142-152. https://doi.org/10.1016/j.gloenvcha.2009.10.002

[10] Federici, S., Tubiello, F.N., Salvatore, M., Jacobs, H. and Schmidhuber, J. (2015) New Estimates of $\mathrm{CO}_{2}$ Forest Emissions and Removals: 1990-2015. Forest Ecology 
and Management, 352, 89-98. https://doi.org/10.1016/j.foreco.2015.04.022

[11] Vedeld, P., Angelsen, A., Bojö, J., Sjaastad, E. and Berg, G.K. (2007) Forest Environmental Incomes and the Rural Poor. Forest Policy and Economics, 9, 869-879. https://doi.org/10.1016/j.forpol.2006.05.008

[12] Charles, A. and Jasper, Y.D. (2016) Forest Fringe Communities Participation in Forest Reserve Sustainability in Ghana. Open Journal of Forestry, 6, 94-105.

[13] Etwire, P.M., Al-hassan, R.M., Kuwornu, J.K.M. and Osei-Owusu, Y. (2013) Application of Livelihood Vulnerability Index in Assessing Vulnerability and Climate Change in Northern Ghana. Journal of Environment and Earth Science, 3, 157-170.

[14] Acquah, H.D. (2011) Farmers' Perception and Adaptation to Climate Change: A Willingness to Pay Analysis. Journal of Sustainable Development in Africa, 13, 150-161.

[15] Donkor, E., Matthew, E., Jnr, O., Prah, B.E.K., Amoah, A.S. and Mohammed, Y. (2016) Estimation and Mapping of Carbon Stocks in Bosomkese Forest Reserve. International Journal of Remote Sensing Applications, 6, 41-52. https://doi.org/10.14355/ijrsa.2016.06.005

[16] Armah, F.A., Odoio, J.O., Yengoh, G.T., Obiri, S., Yawson, D.O. and Afrifa, E.K.A. (2010) Food Security and Climate Change in Drought-Sensitive Savanna Zones of Ghana. Mitigation and Adaptation Strategies for Global Change, 16, 291-306. https://doi.org/10.1007/s11027-010-9263-9

[17] Adusei, C. and Dunyah, J.Y. (2016) Forest Fringe Communities Participation in Forest Reserve Sustainability in Ghana. Open Journal of Forestry, 6, 94-105. https://doi.org/10.4236/ojf.2016.62009

[18] Veuthey, S. and Gerber, J.F. (2010) Logging Conflicts in Southern Cameroon: A Feminist Ecological Economics Perspective. Ecological Economics, 70, 170-177. https://doi.org/10.1016/j.ecolecon.2009.09.012

[19] Dhakal, S. and Sedhain, G.K. (2016) Climate Change Impact and Adaptation Practices in Agriculture: A Case Study of Rautahat District, Nepal. Climate, 4, 63. https://doi.org/10.3390/cli4040063

[20] Goldberg, J.I. and Borgen, P.I. (2006) Breast Cancer Susceptibility Testing: Past, Present, and Future. Expert Review of Anticancer Therapy, 6, 1205-1214. https://doi.org/10.1586/14737140.6.8.1205

[21] Williams, C.A., Collatz, G.J., Masek, J. and Goward, S.N. (2012) Carbon Consequences of Forest Disturbance and Recovery across the Conterminous United States. Global Biogeochemical Cycles, 26, GB1005. https://doi.org/10.1029/2010GB003947

[22] Maryudi, A., Devkota, R.R., Schuster, C., Yufanyi, C., Salla, M., Aurenhammer, H., Rotchanaphatharawit, R. and Krott, M. (2011) Back to Basics: Considerations in Evaluating the Outcomes of Community Forestry. Forest Policy and Economics, 14, 1-5. https://doi.org/10.1016/j.forpol.2011.07.017

[23] Intergovernmental Panel on Climate Change (IPCC) (2007) Climate Change 2007: Synthesis Report. The Contribution of Working Groups I, II and III to the Fourth Assessment Report of the Intergovernmental Panel on Climate Change, Geneva.

[24] Bradford, J.B., Jensen, N.R., Domke, G.M. and D'Amato, A.W. (2013) Potential Increases in Natural Disturbance Rates Could Offset Management Impacts on Ecosystem Carbon Stocks. Forest Ecology and Management, 308, 178-187. https://doi.org/10.1016/j.foreco.2013.07.042

[25] Chhatre, A. and Agrawal, A. (2009) Trade-Offs and Synergies between Carbon 
Storage and Livelihood Benefits from Forest Commons. Proceedings of the National Academy of Sciences of the United States of America, 106, 17667-17670. https://doi.org/10.1073/pnas.0905308106

[26] Boon, E. and Ahhenken, A. (2007) Conservation and Management of Biodiversity in West Africa-Case Study of Ghana in Encyclopedia of Life Support Systems. UNESCO, Paris.

[27] Heinimann, A., Hett, C., Hurni, K., Messerli, P., Epprecht, M., Jørgensen, L. and Breu, T. (2013) Socio-Economic Perspectives on Shifting Cultivation Landscapes in Northern Laos. Human Ecology, 41, 51-62.

[28] Siry, J., Cubbage, F., Newman, D. and Izlar, B. (2010) Forest Ownership and Management Outcomes in the U.S. in Global Context. International Forestry Review, 12, 38-48. https://doi.org/10.1505/ifor.12.1.38

[29] Cadman, T. and Maraseni, T. (2013) More Equal than Others? A Comparative Analysis of State and Non-State Perceptions of Interest Representation and Decision-Making in REDD+ Negotiations. Innovation, 26, 214-230. https://doi.org/10.1080/13511610.2013.771880

[30] Siry, J.P., Frederick, K.M., Cubbage, W. and Bettinger, P. (2015) Forest Tenure and Sustainable Forest Management. Open Journal of Forestry, 5, 526-545.

[31] Fosu-Mensah, B.Y., Vlek, P.L.G. and MacCarthy, D.S. (2012) Farmers' Perceptions and Adaptation to Climate Change: A Case Study of Sekyere Dumase District in Ghana. Environment, Development and Sustainability, 14, 495-505. https://doi.org/10.1007/s10668-012-9339-7

[32] Feldspausch, T.R., Lloyd, J., Lewis, S.L., et al. (2012) Tree Height Integrated into Pantropical Forest Biomass Estimates. Biogeosciences, 9, 3381-3403. https://doi.org/10.5194/bg-9-3381-2012

[33] McKinley, D.C., Ryan, M.G., Birdsey, R.A., Giardina, C.P., Harmon, M.E., Heath, L.S., Houghton, R.A., Jackson, R.B., Morrison, J.F., Murray, B.C., Pataki, D.E. and Skog, K.E. (2011) A Synthesis of Current Knowledge on Forests and Carbon Storage in the United States. Ecological Applications, 21, 1902-1924.

$\underline{\text { https://doi.org/10.1890/10-0697.1 }}$ 


\section{Appendix}

Sample questionnaire used to elicit information in the study area $(\mathrm{N}=330)$, FGDs $(\mathrm{N}=100)$.

\begin{tabular}{ll}
\hline \multicolumn{1}{c}{ Variables } & \multicolumn{1}{c}{ How variables were coded } \\
\hline Determinants of causes of deforestation & \\
Gender & $1=$ male, $2=$ female \\
Education & $1=$ literate, $2=$ illiterate \\
Forest guard services & $1=$ yes, $2=$ no, $3=$ not sure \\
Forest-dependent income & $1=$ low, $2=$ high, $3=$ not sure \\
Household size & $1=$ good, $2=$ poor access, $3=$ no access \\
Access to weather information & $1=$ yes, $2=$ no, $3=$ not sure \\
Alternative livelihood & $1=$ yes, $2=$ no, $3=$ not sure \\
Cost of inputs & $1=$ yes, $2=$ no, $3=$ not sure \\
High temperature and low rainfall & $1=$ high, $2=$ low, $3=$ moderate, $4=$ don't know \\
Poor farm yield & $1=$ high, $2=$ low, $3=$ moderate, $4=$ don't know
\end{tabular}

\section{Livelihood economic activity}

Charcoal business

Hunting

Agriculture

Trading

Wood logging

Awareness of deforestation

Direct causes of deforestation

Charcoal burns

Farming

Over grazing

Wood logging

\section{Indirect causes of deforestation}

Population growth

High illiteracy rate

Poverty

Lack of alternative livelihood

Poor government policies
$1=$ high, $2=$ low, $3=$ moderate, $4=$ don't know

1 = high, 2 = low, 3 = moderate, $4=$ don't know

1 = high, 2 = low, $3=$ moderate, $4=$ don't know

$1=$ high, $2=$ low, $3=$ moderate, $4=$ don't know

$1=$ high, 2 = low, $3=$ moderate, $4=$ don't know

$1=$ yes, $2=$ no

$$
\begin{aligned}
& 1=\text { yes, } 2=\text { no, } 3=\text { not sure } \\
& 1=\text { yes, } 2=\text { no, } 3=\text { not sure } \\
& 1=\text { yes, } 2=\text { no, } 3=\text { not sure } \\
& 1=\text { yes, } 2=\text { no, } 3=\text { not sure }
\end{aligned}
$$

$$
\begin{aligned}
& 1=\text { yes, } 2=\text { no, } 3=\text { not sure } \\
& 1=\text { yes, } 2=\text { no, } 3=\text { not sure } \\
& 1=\text { yes, } 2=\text { no, } 3=\text { not sure } \\
& 1=\text { yes, } 2=\text { no, } 3=\text { not sure } \\
& 1=\text { yes, } 2=\text { no, } 3=\text { not sure }
\end{aligned}
$$

